\title{
KIRJA-ARVOSTELU: TUTKIMUSTA MITTAREIDEN TÄHDEN
}

\author{
Bibliometriikan perusajatuksena oli alun perin hyvien viittausten \\ löytäminen ja tiedonhankinnan edistäminen. Viittausraporteista \\ käynnistyi bibliometriikkapohjaisen arvioinnin kultakausi, joka \\ jatkuu yhä. Artikkelikokoelma Gaming the Metrics kuvaa, miten \\ tieteen uudet pelisäännöt vaikuttavat tieteelliseen kulttuuriin.
}

$\mathrm{T}$ iedejulkaisemisen nykytodellisuus näyttäytyy uutisvirrassa huolestuttavalta. Siihen liittyvät käsitteet, kuten saalistajajulkaisut, Retraction Watch, salami slicing, hallitsemattoman tuntuisesti kasvavat julkaisumäärät, tekaistut kirjoittajat ja viittauskartellit, ovat tulleet tutuiksi yhä useammille. Onko vilpillisiä keinoja kaihtamattomien tutkijoiden määrä kasvanut, vai mistä on kyse?

Kaiken takana on Goodhardtin laki: Kun mittarista tulee tavoite, se lakkaa olemasta hyvä mittari. Tämä voitiin todeta bibliometriikassa, jonka perusajatuksena oli alun perin ollut hyvien viittausten löytäminen. Eugene Garfield oli I960-luvulla markkinoinut viittausseurantaan kehitettyä tuotettaan, Science Citation Indexiä (sCI) lähinnä tiedonhankinnan välineeksi.

I970-luvulla scI-tietoihin kohdistunut mielenkiinto kasvoi huomattavasti, kun Garfield lisäsi tuotevalikoimaan lehtien viittausraportit. Uusi Impact Factor (IF) lupasi tietoa lehdistä, joissa viittaussaalis olisi keskimäärin suurempi kuin muissa. Näin käynnistynyt lehtien rankkaus käynnisti bibliometriikkapohjaisen arvioinnin kultakauden, joka jatkuu yhä. Vasta 20 Io-luvulla kriittiset kannanotot ja vastuullisen metriikan suositukset alkoivat hiukan hillitä valtaisaa arviointi-innostusta.
Mario Biaggiolin ja Alexandra Lippmanin toimittamassa teoksessa Gaming the Metrics (2020) on Yves Gingrasin artikkeli, jossa hän kuvailee, miten tiedejulkaisu on muuttunut tiedon yksiköstä kirjanpitoyksiköksi, jolla voidaan punnita niin tutkijoita kuin tutkimusyksiköitäkin. Viittaukset ovat ikään kuin symbolista luotonantoa harvoille ja valituille. Jos julkaisun tietosisältö olisi keskiössä, julkaisujen pitkiä tekijälistauksia ei tarvittaisi tietokannoissa, vaan ensimmäinen tekijä riittäisi tiedon löytämiseen - arviointi sen sijaan edellyttää, että jokainen tekijä kirjataan pikkutarkasti. Ja koska tietosisältö ei enää ole keskiössä, julkaisuja ei tarvitse lukea, kunhan niistä saadaan lukuja. Viittauksia kertyy kuitenkin aivan liian hitaasti, joten ne voidaan korvata kätevästi lehtien IF-luvuilla. Kun me bibliometrikot nykyään korostamme, ettei lehden IF kerro mitään yksittäisen artikkelin sisällöstä, tunnemme itsemme usein kapuloiksi taloudellisuuden ja tehokkuuden rattaissa.

Sama nopeuden pyrkimys on antanut nostetta myös altmetriikalle, joka tuottaa nopeasti lukuja, jotka

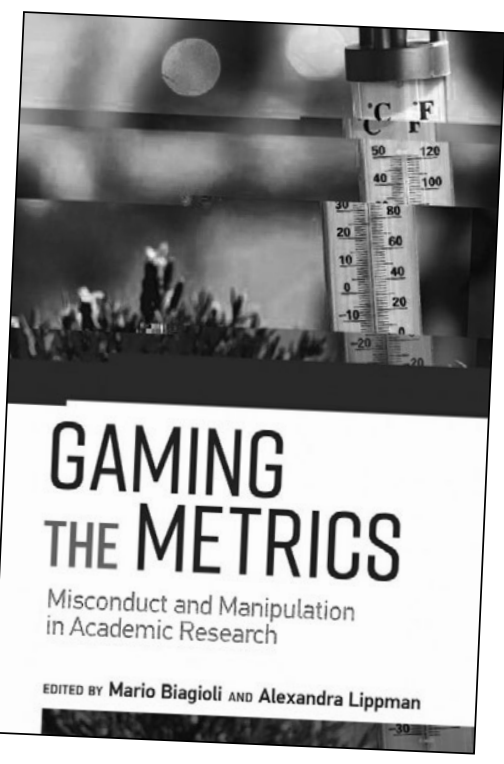




\section{8}

eivät suinkaan ole vaihtoehto viittauksille - sen sijaan ne ovat aivan muuta kuin viittauksia, eivätkä toimi viittaussuhteiden verkostona, askelina tiedosta uuteen tietoon.

Michael Power kuvailee artikkelissaan, miten yhteiskunnallisen vaikuttavuuden mukaan ottaminen Ison-Britannian REF2OI4-arvioinnissa johti siihen, että järjestelmän hyväksikäyttöä (gaming) ei enää voinut erottaa järjestelmän normaalista toiminnasta. Tulevasta yhteiskunnallisesta vaikuttavuudesta piti kerätä lausuntoja ennen kuin mitään vaikutusta oli vielä ollutkaan. Arvioitavien yksiköiden piti siksi löytää hyviä vaikutuskohteita (good impactees), joihin suhteita kannatti ylläpitää, jotta saataisiin sopivaa tekstiä myös tuleviin vaikuttavuusperusteluihin.

V

astuullisessa metriikassa muistutetaan usein asiantuntijaarvioinnin ja metriikan käytöstä rinnakkain niin, että toinen tukee toista. Tällainen suoraviivainen "valistunut vertaisarviointi" ei ota huomioon, että metriikka on ehtinyt luikerrella käärmeeksi asiantuntijoiden näkemyksiin ja arvioitavien tutkijoiden käyttäytymiseen. Viitatessaan tutkija joutuu pohtimaan, hyödyttääkö tehty viittaus häntä, vai pitäisikö valita jokin toinen viittauksen kohde. Paul Wouters pohtii, että tällaisessa vertaisarviointiprosessissa kenties siivilöidään pois uusia innovaatioita, koska niihin ei ole uskallettu viitata. Siksi kaikkeen arviointiin tarvitaan konteksti, jonka tulisi toimia tarkastelun keskeisenä elementtinä.
Kun toimintaympäristö ja oman toiminnan arviointi ovat muuttuneet näinkin haasteellisiksi, mitä yksittäinen tutkija voi tehdä? James Griesemer kuvailee voimattomuuden tunnetta: "Määrällisiin tavoitteisiin perustuvat käytännöt ja suuntaviivat muuttavat työsuoritukset, tutkimustyö mukaan lukien, peliksi, missä tavoitteena on tavoitteen ylittäminen sen sijaan että tehtäisiin sitä työtä, joka oli mittauskohteena." Metriikan vuorovesi nousee, koska saatavilla oleva data on digitaalista merta liikuttelevan painovoiman kaltainen - mitä isompaa dataa meillä on, sen suurempia aaltoja.

Entäpä jos tutkijat eivät tietäisi, mitä indikaattoreita korissamme on? He eivät voisi pelata metriikkapelejäainakaan siihen asti, kun heille tavalla tai toisella selviäisi, millä säännöillä pelataan. Tämä on kumminkin mahdoton lähestymistapa, sillä tavoitteiden tulee olla läpinäkyviä. Kuinka muuten tutkijat tietäisivät, millaisia tavoitteita heillä on täytettävänään? Griesemer ehdottaa, että perustettaisiin julkaisuja nimeltä "Public Library of Philosophy" (PuLP), joiden tarkoituksena olisi testata Goodhardtin lakia läpinäkyvin testein. Kun tietäisimme tarkoin, miten järjestelmä toimii, se olisi kaikille läpinäkyvä.

Avoimena julkaistussa Gaming the Metrics sisältää laajan kirjon artikkeleita, joissa tarkastellaan tieteen uusia pelisääntöjä monesta eri kulmasta. Usein juhlallisilta tuntuvien vastuullisuusjulistusten rinnalla teksti on virkistävää ja ajatuksia herättävää luettavaa.

\section{Kirjoittaja}

Eva IsAKsson

Helsingin yliopiston kirjasto

eva.isaksson@helsinki.fi 